Shaw, G. R. (1914): The genus Pinus. Arnold Arboretum Publication No. 5, Houghton Mifflin Corporation, Boston.

SHEPHERD, M. and R. HENRY (2002): Identifizierung von Hybriden von Pinus elliottii var. elliottii $\times$ P. caribaea var. hondurensis mittels Chloroplasten trn L-F intergenischen Abständen. Silvae Genetica 51: 273-277.

Staszkiewicz, J. (1996): Natural hybrids of Pinus mugo $\mathrm{x}$ P. sylvestris (Pinaceae) in Tatra Mts. Fragmenta Floristica et Geobotanica, Series Polonica 3: 23-30.

Staszkiewicz, J. and M. TYszKiewicz (1969): Natural hybrids of Pinus mugo Turra $\mathrm{x}$ Pinus sylvestris L. in Nowy Targ valley. Fragmenta Floristica et Geobotanica 15: $187-212$.

Viewegh, J. (1981): Variability of the hybrid swarms Pinus mugo x Pinus sylvestris on peat-bog in Zuberec, Orava. Folia Dendrologica 8: 41-59.

VieweGH, J. and C̆AMBALOVA, H. (1993): Variability of hybrid swarm Pinus $\mathrm{x}$ celakovskiorum A. et Gr. processed with some cluster analysis methods. Biologia (Bratislava) 48: 39-44.

WACHOWIAK, W., K. LEŚNIEWICZ, I. J. ODRZYKOSKI, H. Augustyniak and W. Prus-Glowacki (2000): Speciesspecific cpDNA markers useful for studies on the hybridization between Pinus mugo and P. sylvestris. Acta Societatis Botanicorum Poloniae 69: 273-276.

WACHOWIAK, W., A. LeWANDOWSKI and W. PRUs-GlOWACKI (2005): Reciprocal controlled crosses between Pinus sylvestris and $P$. mugo verified by a species-specific cpDNA marker. Journal of Applied Genetics 46: 41-43.

WACHOWIAK, W., I. OdRzYKoski, L. MYczKo and W. PRUSGLOWACKI (2006a): Lack of evidence on hybrid swarm in the sympatric population of Pinus mugo and $P$. sylvestris. Flora 201: 307-316.

Wachowiak, W., B. R. Stephan, I. Schulze, W. PrusGLOWACKI and B. ZIEGENHAGEN (2006b): A critical evaluation of reproductive barriers between closely related species using DNA markers - a case study in Pinus. Plant Systematics and Evolution 257: 1-8.

Wagner, D. B., G. R. Furnier, M. A. Saghai-Maroof, S. M. Williams, B. P. DanciK and R. W. Allard (1987): Chloroplast DNA polymorphism in lodgepole pines and jack pines and their hybrids. Proceeding of the National Academy of Sciences U.S.A. 84: 2097-2100.

Wagner, D. B., D. R. Govindaraju, C. W. Yeatman and J. A. Pitel (1989): Paternal chloroplast DNA inheritance in a diallel cross of jack pine (Pinus banksiana Lamb.). The Journal of Heredity 80: 483-485.

WANG, X.-R., A. E. SzMidt, A. LeWANDOWski and Z.-R. WANG (1990): Evolutionary analysis of Pinus densata Masters, a putative tertiary hybrid. Theoretical and Applied Genetics 80: 635-640.

WATANO, Y., A. KANAI and N. TANI (2004): Genetic structure of hybrid zones between Pinus pumila and P. parviflora var. pentaphylla (Pinaceae) revealed by molecular hybrid index analysis. American Journal of Botany 91: 65-72.

\title{
Primer Note: A New Set of Highly Polymorphic Nuclear Microsatellite Markers for Nothofagus nervosa and Related South American Species
}

\author{
By P. Marchelli ${ }^{\left.1),{ }^{*}\right)}$, H. Caron ${ }^{2)}$, M. M. AzPilicueta ${ }^{1)}$ and L. A. Gallo ${ }^{1)}$
}

(Received 13 $3^{\text {th }}$ March 2007)

\begin{abstract}
Nothofagus is the main component of southern South American temperate forests. Overexploitation in the past has led to the loss of $40 \%$ of the original distribution range. Genetic diversity as well as biological processes shaping the distribution of the genetic variation (e.g. gene flow) constitutes basic knowledge for the implementation of conservation measures and for the definition of Evolutionary Significant Units. Nuclear microsatellites are the marker of choice for gene flow and fine-scale genetic structure studies. We enlarged a

1) Forest Genetic Unit, INTA EEA Bariloche, CC 277, 8400 Bariloche, Argentina.

2) INRA-UMR BIOGECO, 69 route d'Arcachon, 33612 Cestas cedes, France.

*) Correspondence author: PaUla Marchelli, INTA EEA Bariloche, Unidad de Genética Forestal, CC 277, 8400 Bariloche, Argentina. Fax: 00542944 422731. Email: pmarchelli@ bariloche.inta.gov.ar.
\end{abstract}

previous set of microsatellites (SSRs) for South American Nothofagus species, with special concern to Nothofagus nervosa (Phil.) Dim. et Mil. Five new SSRs are presented with allele numbers up to 12 in a single population. The primers transferred well to five related species (N. obliqua (Mirb.) Oerst, N. glauca (Phil.) Krasser, $N$. dombeyi (Mirb.) Oerst , N. pumilio (Poepp et Endl.) Krasser and $N$. antarctica (G. Forster) Oerst, with allele numbers up to 11 . The high level of polymorphism promises a sufficient power for gene flow and parentage analyses.

Key words: Nothofagus, microsatellites, South America, gene flow, fine-scale genetic structure.

\section{Introduction}

Nothofagus is the dominant genus of southern South American temperate forests, with a total of ten endemic species. In the last century, over-exploitation, over 
grassing, recurrent forest fires and agricultural settlement provoked the loss of $40 \%$ of the original distribution range (LARA et al., 1999). Conservation and domestication programs for maintaining the genetic resources and genetic diversity of some of the species have begun both in Chile and Argentina. Genetic studies have been conducted in some of the species with genetic markers such as isozymes (e.g. Premol, 1997; MARchelli and GALlo, 2001; Donoso et al., 2004), chloroplast DNA (MARChELli and GALlO, 2006), ISSR and RAPDs (MATTIONI et al., 2002). However, for gene flow studies and fine-scale genetic diversity analyses highly polymorphic nuclear microsatellites (SSRs) are the marker of choice. Microsatellites have been developed for Australian Nothofagus (JonEs et al., 2004). Besides, transference of Quercus SSRs and the development of three nuclear microsatellites for South American Nothofagus were reported (MARCHELli and GALlo, 2000; AzPILICUETA et al., 2004). Notwithstanding, additional loci are needed since among the three markers developed for South American species the number of alleles was lower than expected and amount of polymorphism was not enough for parentage analyses.

Here we present the development of an enlarged set of microsatellite markers for Nothofagus nervosa (Phil.) Dim. et Mil. (= N. alpina (Poepp. et Endl.) Oerst) for their use in gene flow and fine-scale genetic structure studies. Additionally, Mendelian inheritance was evaluated by analyzing the segregation of alleles among mothers and half sibs. The cross-amplification in five related species was also tested.

\section{Materials and Methods}

A microsatellite library was developed in Nothofagus nervosa using the microsatellite enrichment protocol (EDWARDS et al., 1996) and selective hybridization with the $(\mathrm{AC})_{\mathrm{n}}$ and $(\mathrm{AG})_{\mathrm{n}}$ insert repeats. PCR products were cloned using the Topo TA cloning Kit (Invitrogen) and sequenced on a Megabace1000 DNA analysis system using the cycle sequencing kit (Amersham Biosciences) according to manufacturer's instructions. Suitable sequences were selected and used to design PCR primers using the freely distributed software Primer 3 on the WWW (ROZEN and SKALETSKY, 2000).
To characterize the isolated microsatellites, buds from 25 Nothofagus nervosa trees from Tromen Lake in Argentina were collected. To test Mendelian segregation, 20 progenies from each of twelve of the mother trees obtained as open-pollinated seed were sampled. DNA was isolated following the procedure by DuMOLIN et al. (1995) with slight modifications according to MARCHELLI et al. (1998). PCRs were performed in a total volume of $20 \mu \mathrm{l}$ containing $10 \mathrm{x}$ PCR buffer (containing $200 \mathrm{mM}$ Tris-HCl pH 8.4; $500 \mathrm{mM} \mathrm{KCl}$; final concentration $1 \mathrm{x}$ ), between 1.5 to $2.5 \mathrm{mM} \mathrm{MgCl}_{2}$ (Table 1), $0.1 \mathrm{mM}$ dNTPs, $0.2 \mu \mathrm{M}$ of each primer, $0.6 \%$ BSA, $1 \mathrm{U}$ Taq polymerase (Invitrogen) and $25 \mathrm{ng}$ of template DNA. Reactions were performed using a MJ Research PT-200 thermo cycler with the following profile: a hot start of $95^{\circ} \mathrm{C}$ for $5 \mathrm{~min}$., followed by 35 cycles of denaturing at $94^{\circ} \mathrm{C}$ for $1 \mathrm{~min}$., annealing temperature (Table 1) for $1 \mathrm{~min}$, and extension at $72^{\circ} \mathrm{C}$ for $1 \mathrm{~min}$., with a final extension at $72^{\circ} \mathrm{C}$ for $7 \mathrm{~min}$. PCR products were denatured by the addition of $95 \%$ formamide, $0.1 \%$ bromophenol blue, $0.1 \%$ xylene cyanol and 0.5M EDTA pH $=8$ and heating at $94^{\circ} \mathrm{C}$ for 6 minutes. Denatured PCR products were run in $6 \%$ polyacrylamide sequencing gels containing $7 \mathrm{M}$ urea in $1 \mathrm{x}$ TBE buffer. Gels were silver-stained following the protocol of STREIFF et al. (1998) and the image scanned. For the determination of allele size, different genotypes were selected and run in an ABI 3100 sequencer (Applied Biosystems). Observed and expected heterozygosities, deviations from Hardy-Weinberg expectations and linkage disequilibrium among loci were calculated using GENEPOP version 3.4 (RAYMOND and RousSET, 1995). These analyses were done with the population samples, not including the offspring.

Cross-amplification was examined in five South American Nothofagus species: Nothofagus obliqua (Mirb.) Oerst, N. dombeyi (Mirb.) Oerst, N. pumilio (Poepp et Endl.) Krasser and N. antarctica (G. Forster) Oerst (15 individuals each) and $N$. glauca (Phil.) Krasser, (9 individuals).

\section{Results and Discussion}

Six microsatellites gave a good amplification product with scorable bands. The others showed no amplification or multiple band patterns. Among these six SSR loci,

Table 1. - Characterization of five Nothofagus nervosa SSR loci.

\begin{tabular}{|c|c|c|c|c|c|c|c|c|c|c|}
\hline Locus & Primer sequence & Repeat & $\begin{array}{c}\mathrm{T}_{\mathrm{a}} \\
\left({ }^{\circ} \mathrm{C}\right)\end{array}$ & $\begin{array}{c}\mathrm{MgCl}_{2} \\
\text { concentration }\end{array}$ & $\begin{array}{c}\text { Size } \\
\text { range } \\
\text { (bp) }\end{array}$ & $A$ & $A_{\text {off }}$ & $H_{o}$ & $H_{e}$ & $\begin{array}{c}\text { GenBank } \\
\text { accession no. }\end{array}$ \\
\hline NnBIO 10 & $\begin{array}{l}\text { F: GATCCCACATGTCCTTGGTC } \\
\text { R: TGGACCGATAAGAATGTCAGC }\end{array}$ & $(\mathrm{CA})_{17}$ & 53 & 1.5 & $262-292$ & 8 & 12 & $1.0^{*}$ & 0.803 & AM408112 \\
\hline NnBIO 111 & $\begin{array}{l}\text { F: TATGTGAACGCGTCTGCTTC } \\
\text { R: CGCTCTTCAGACCAGAAAGG }\end{array}$ & $(\mathrm{GT})_{2} \mathrm{~A}(\mathrm{GT})_{10}$ & 53 & 2.0 & $121-137$ & 6 & 9 & 0.625 & 0.604 & AM408113 \\
\hline NnBIO 37 & $\begin{array}{l}\text { F: CAACGACTGTTCCCAACTCC } \\
\text { R: TTACCTGGTGGGAGATTTCG }\end{array}$ & $(\mathrm{CT})_{12}$ & 59 & 1.5 & $111-135$ & 8 & 10 & $1.0^{*}$ & 0.834 & AM408114 \\
\hline NnBIO 72 & $\begin{array}{l}\text { F: TAAGTGGGGTGGTTTCCAAC } \\
\text { R: ATTCCCATCCTACCCCTGAC }\end{array}$ & $(\mathrm{TTC})_{7}$ & 54 & 2.5 & $149-179$ & 7 & 11 & 0.700 & 0.768 & AM408115 \\
\hline NnBIO 90 & $\begin{array}{l}\text { F: TCCCCTATTCTTGACCAACC } \\
\text { R: TGGTTTTATTGGTGGAAATGG }\end{array}$ & $(\mathrm{GT})_{4} \mathrm{G}(\mathrm{GT})_{2} \mathrm{GC}(\mathrm{GT})_{2}$ & 57 & 1.5 & 401 & 1 & 1 & 0 & 0 & AM408116 \\
\hline
\end{tabular}

$\mathrm{T}_{\mathrm{a}}$ : Annealing temperature, $\mathrm{H}_{\mathrm{o}}$ and $\mathrm{H}_{\mathrm{e}}$ : observed and expected heterozygosities, $A$ : allele number, $A_{\text {off }}$ :allele number including offspring. * Significant heterozygote excess $(\mathrm{P}<0.05)$. 
Table 2. - Number of alleles of five SSR loci in Nothofagus nervosa and related Nothofagus species.

\begin{tabular}{lcccccc}
\hline Species & $\mathrm{N}$ & NnBIO 10 & NnBIO 111 & NnBIO 37 & NnBIO 72 & NnBIO 90 \\
\hline N. nervosa & 25 & 8 & 6 & 8 & 7 & 1 \\
\hline N. obliqua & 15 & 11 & 8 & 5 & 5 & 2 \\
N. glauca & 9 & 4 & 1 & 6 & 6 & 3 \\
N. antarctica & 15 & 6 & 6 & 7 & 4 & 1 \\
N. pumilio & 15 & 6 & 5 & 5 & 3 & 1 \\
N. dombeyi & 15 & 6 & 4 & 8 & 6 & 1 \\
\hline
\end{tabular}

$\mathrm{N}$ : number of individuals tested. Annealing temperatures are the same as in $N$. nervosa, except for NnBIO37 in $N$. antarctica, $N$. pumilio and $N$. dombeyi which is $55^{\circ} \mathrm{C}$.

one was monomorphic in $N$. nervosa and all related species, and therefore discarded from further analyses. For the remaining microsatellites, the number of alleles observed ranged from six to eight among the adult trees, but was higher when including the offspring reaching values of up to 12 alleles in NnBIO10 (Table 1). A particular case is locus NnBIO90 which was monomorphic in most of the species, but presented two and three alleles in $N$. obliqua and $N$. glauca respectively. It was monomorphic in the analysed samples of $N$. nervosa, and therefore not suitable as a microsatellite marker for gene flow studies. However, the presence of different alleles among $N$. nervosa and $N$. obliqua suggests the potential use of this locus as a diagnostic marker in studies of the natural hybridization between these two species. Segregation of alleles was proved by analyzing the maternal genotype together with the seedlings. Observed heterozygocities ranged between 0.625 and 1.0, while expected values were between 0.604 and 0.835 (Table 1). Significant heterozygote excess was observed for loci NnBIO10 and NnBIO37 ( $<<0.05)$. The Fisher's test did not reveal any significant case of linkage disequilibrium.

Cross-amplification was successful in all the related species for the five primers and allele number ranged from one to 11 (Table 2). The allele sizes were more similar between species belonging to the same taxonomic clade. According to the phylogeny presented by Manos (1997) $N$. nervosa, N. obliqua and $N$. glauca form one taxonomic subgroup within the subgenera Lophozonia, while $N$. antarctica, $N$. dombeyi and $N$. pumilio belong to the subgenera Nothofagus. Within each subgroup most of the species hybridize naturally (e.g. GALLO et al., 1997; STECONNI et al., 2004). The existence of speciesspecific alleles for studying the hybridization was observed between $N$. nervosa and $N$. obliqua (data not shown) and the possibility of finding specific alleles for the other species is open.

The levels of polymorphism detected in $N$. nervosa with the SSRs described in the present work is very promising for their application to gene flow and finescale diversity studies. Furthermore, since sampling was done within one population an enlarged number of alleles are expected when extending the range. At present, the described microsatellites are being used for pollen flow studies and fine-scale structure of genetic diversity. Preliminary data from one population indicates that the exclusion probability is higher than $90 \%$ (unpublished data).

\section{Acknowledgements}

We thank A. MARTINEZ MEIER for field assistance and M. Milleron and C. Soliani for laboratory help. Helpful comments from two anonymous reviewers are also acknowledged. This study was financed by different projects: BES (British Ecological Society, Small Grants N $^{\circ}$ 2258), PIP CONICET (5451). The ABI3100 facility was acquired through the project PME $\mathrm{N}^{\circ} 71$. P. MARCHELLI is a researcher from CONICET.

\section{References}

Azpilicueta, M. M., H. Caron, C. Bodénès and L. A. GALLO (2004): SSR markers for analysing South American Nothofagus species. Silvae Genetica 53, 240-243.

Donoso, C., L. A. Gallo, P. Donoso and M. M. AzPILICUETA (2004): Variación en Nothofagus obliqua (Mirb.) Oerst. pp 115-144. In: Variación intraespecífica en especies arbóreas de los bosques templados de Chile y Argentina, edited by Donoso, C., Premoli, A., Gallo, L., IPINZA, R. Editorial Universitaria, Santiago, Chile.

Dumolin, S., B. Demesure and R. J. Petit (1995): Inheritance of chloroplast and mitochondrial genomes in pedunculate oak investigated with an efficient PCR method. Theoretical and Applied Genetics 91, 1253-1256.

Edwards, K. J., J. H. A. Barker, A. Daly, C. Jones and A. KARP (1996): Microsatellite libraries enriched for several microsatellites sequences in plants. Biotechniques 20, 758-760.

Gallo, L. A., P. Marchelli and A. BreitembüCher (1997): Morphological and allozymic evidence of natural hybridization between two southern beeches (Nothofagus spp.) and its relation to heterozygosity and height growth. Forest Genetics 4, 15-23.

Jones, R. C., R. E. VAillancourt and G. J. JoRdan (2004): Microsatellites for use in Nothofagus cunninghamii (Nothofagaceae) and related species. Molecular Ecology Notes 4: 14-16.

Lara, A., P. Rutherford, C. Montory, D. Bran, A. Perez, S. Clayton, J. Ayesa, D. Barrios, M. Gross and G. IGLESIAS (1999): Mapeo de la Eco-región de los bosques Valdivianos. Fundación Vida Silvestre Argentina, Buenos Aires. Boletín Técnico de la Fundación Vida Silvestre Argentina 51, 1-27.

Manos, P. S. (1997): Systematics of Nothofagus (Nothofagaceae) based on rDNA spacer sequences (ITS): Taxonomic congruence with morphology and plastid sequences. American Journal of Botany 84, 1137-1155.

Marchelli, P., L. Gallo, F. Scholz and B. Ziegenhagen (1998): Chloroplast DNA markers revealed a geographical divide across Argentinean southern beech Nothofagus nervosa (Phil.) Dim. et Mil. distribution area. Theoretical and Applied Genetics 97, 642-646. 
Marchelli, P. and L. A. Gallo (2000): Variación aloenzimática, de $\mathrm{ADN}$ de cloroplasto y de $\mathrm{ADN}$ nuclear en poblaciones y progenies de raulí en Argentina. pp 157-180. In: Domesticación y mejora genética de raulí y roble, edited by IPINZA, R., GutiÉRrez, B. and EMHART, V. Universidad Austral de Chile, Instituto Forestal, Valdivia, Chile.

Marchelli, P. and L. A. Gallo (2001): Genetic diversity and differentiation in a southern beech subjected to introgressive hybridisation. Heredity 87, 284-293.

MARCHELLI, P. and L. A. GALLO (2006): Multiple ice-age refugia in a southern beech from southern South America as revealed by chloroplast DNA markers. Conservation Genetics 7, 591-603.

Mattioni, C., M. Casasoli, M. Gonzalez, R. Ipinza and F. VILLANI (2002): Comparison of ISSR and RAPD markers to characterize three Chilean Nothofagus species. Theoretical and Applied Genetics 104, 1064-1070.

Premoli, A. C. (1997): Genetic variation in a geographically restricted and two widespread species of South American Nothofagus. Journal of Biogeography 24, 883-892.
RAYMOND, M. and F. Rousset (1995): GENEPOP: Population Genetics Software for exact tests and ecumenicism. The Journal of Heredity 86, 248-249.

Rozen, S. and H. J. Skaletsky (2000): Primer3 on the WWW for general users and for biologist programmers. pp 365-386. In: Bioinformatics Methods and Protocols: Methods in Molecular Biology, edited by KRAwETZ, S., Misener, S. Humana Press, Totowa, NJ.

Stecconi, M., P. Marchelli, P. Picca, J. Puntieri and L. A. Gallo (2004): Natural hybridization between a deciduous (Nothofagus antarctica) and an evergreen (N. dombeyi) forest tree species as evidenced by morphological and isoenzymatic traits. Annals of Botany 94, 775-786.

Streiff, R., T. Labbe, R. Bacilieri, H. Steinkellner, J. GLÖSSL and A. KREMER (1998): Within population genetic structure in Quercus robur L. and Quercus petraea (Matt.) Liebl. assessed with isozymes and microsatellites. Molecular Ecology 7, 317-328.

\title{
Genetic Variation in the Qinghai-Tibetan Plateau Endemic and Endangered Conifer Cupressus gigantea, Detected Using RAPD and ISSR Markers
}

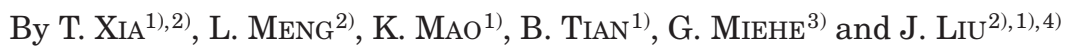 \\ MOE Key Laboratory of Arid and Grassland Ecology, \\ School of Life College, Lanzhou University, Lanzhou, 730000, China
}

(Received 21 $1^{\text {th }}$ September 2007)

\begin{abstract}
Assessing the level and distribution of genetic diversity of rare tree species is essential for their management and the development of effective conservation strategies. Cupressus gigantea is a long-lived endemic cypress of the west Qinghai-Tibetan Plateau and the tallest tree in its genus. The current populations of this species are fragmented and highly disturbed. We used RAPD (Random Amplified Polymorphic DNA) and ISSR (Inter-Simple Sequence Repeat amplification) markers to assess the genetic variation and population structure of this

1) MOE Key Laboratory of Arid and Grassland Ecology, School of Life College, Lanzhou University, Lanzhou, 730000, China.

2) Laboratory of Adaptation and Evolution of Plateau Biota, Northwest Plateau Institute of Biology, Chinese Academy of Sciences, Xining, 810001, Qinghai, China.

$\left.{ }^{3}\right)$ Faculty of Geography, University of Marburg, Deutschhausstr. 1035032 Marburg, Germany.

$\left.{ }^{4}\right)$ Corresponding author: Dr. JIANQUAN LIU (MOE Key Laboratory of Arid and Grassland Ecology, Lanzhou University, Lanzhou, 730000, China. Tel. +86-971-6153387, Fax. +86-971-6143282. E-mail: liujq@nwipb.ac.cn
\end{abstract}

endangered cypress. The 15 RAPD primers used in this study amplified 108 reproducible bands, 49 (45.4\%) of which were polymorphic, while the 12 ISSR primers amplified 94 bands, $65(69.2 \%)$ of which were polymorphic. Analysis of Molecular Variance (AMOVA) indicated that $49.7 \%$ and $38.3 \%$ of the variation was attributable to differences between populations for the RAPD and ISSR markers, respectively; relatively high compared to values reported for other conifer species. These estimates were also similar to Gst values obtained from Nei's gene diversity analyses $($ RAPD $=0.41$ and ISSR $=$ 0.36 ), and suggest that there is a high degree of population differentiation in this narrowly-distributed conifer. The genetic structure of this species has probably been shaped by its long life cycle and climatic changes during the Quaternary. The high degree of population differentiation in this species highlights the need for additional conservation measures, including measures to protect of all of the remaining populations. The substantial similarities between the results of the RAPD and ISSR analyses of samples from the same individuals indicate that they can be interpreted with high levels of confidence. 